\title{
"The essence and features of the competency-based approach to strategic enterprise management"
}

\begin{tabular}{|c|c|c|}
\hline AUTHORS & \multicolumn{2}{|l|}{ Inna Gruzina (iD) } \\
\hline ARTICLE INFO & \multicolumn{2}{|c|}{$\begin{array}{l}\text { Inna Gruzina (2020). The essence and features of the competency-based } \\
\text { approach to strategic enterprise management. Development Management, 18(4), } \\
\text { 30-40. doi:10.21511/dm.18(4).2020.04 }\end{array}$} \\
\hline DOI & \multicolumn{2}{|c|}{ http://dx.doi.org/10.21511/dm.18(4).2020.04 } \\
\hline RELEASED ON & \multicolumn{2}{|l|}{ Friday, 20 August 2021} \\
\hline RECEIVED ON & \multicolumn{2}{|l|}{ Monday, 30 November 2020} \\
\hline ACCEPTED ON & \multicolumn{2}{|l|}{ Friday, 18 December 2020} \\
\hline & \multicolumn{2}{|l|}{$((c)) \mathrm{EY}$} \\
\hline LICENSE & \multicolumn{2}{|c|}{$\begin{array}{l}\text { This work is licensed under a Creative Commons Attribution } 4.0 \text { International } \\
\text { License }\end{array}$} \\
\hline JOURNAL & \multicolumn{2}{|l|}{ "Development Management" } \\
\hline ISSN PRINT & \multicolumn{2}{|l|}{$2413-9610$} \\
\hline ISSN ONLINE & \multicolumn{2}{|l|}{$2663-2365$} \\
\hline PUBLISHER & \multicolumn{2}{|c|}{ LLC "Consulting Publishing Company "Business Perspectives" } \\
\hline FOUNDER & \multicolumn{2}{|c|}{ Simon Kuznets Kharkiv National University of Economics } \\
\hline \multirow[b]{2}{*}{ NUMBER OF REFERENCES } & & 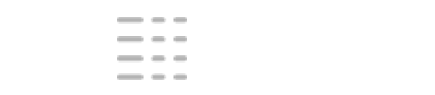 \\
\hline & NUMBER OF FIGURES & NUMBER OF TABLES \\
\hline 27 & 1 & 1 \\
\hline
\end{tabular}

(C) The author(s) 2021. This publication is an open access article. 


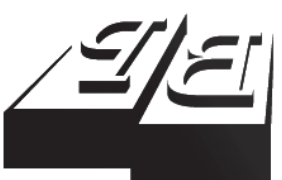

BUSINESS PERSPECTIVES

Publisher

LLC "CPC "Business Perspectives" Hryhorii Skovoroda lane, 10, Sumy, 40022, Ukraine

www.businessperspectives.org

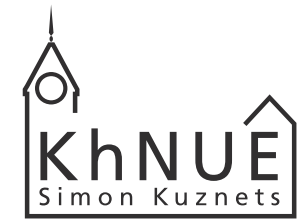

\section{S. KUZNETS KHNUE}

\section{Founder}

Simon Kuznets Kharkiv National University of Economics, Nauky avenue, 9-A, Kharkiv, 61166,

Ukraine

http://www.hneu.edu.ua/

Received on: 30th of November, 2020 Accepted on: 18th of December, 2020 Published on: 20th of August, 2021

\section{(C) Inna Gruzina, 2021}

Inna Gruzina, Ph.D. in Economics, Associate Professor of the Department of Management and Business, S. Kuznets Kharkiv National University of Economics, Ukraine.
Inna Gruzina (Ukraine)

\section{THE ESSENCE AND FEATURES OF THE COMPETENCY-BASED APPROACH TO STRATEGIC ENTERPRISE MANAGEMENT}

\begin{abstract}
Increasing the role of an employee as a determining factor in the economic growth of an enterprise makes managers change the philosophy of management, directing it towards the realization of employees' unique abilities. The effective implementation of the strategic direction of action depends on the knowledge, skills and personal characteristics of specialists, i.e. competencies that are a source of competitive advantage and a strategic factor in the enterprise development. In this regard, it is necessary to study the competency-based approach features in order to identify the opportunities for application in the strategic management of an enterprise. The purpose of the study is to clarify the essence of the competency-based approach and substantiate the need for its application in strategic management. The object of the study is the process of strategic enterprise management. The following methods were used: abstract-logical, analysis and synthesis - to clarify the essence of the competency-based approach; formation of conclusions; and graphical technique - to visualize the results. The views on the essence of the competency-based approach are analyzed and the lack of research on its importance for ensuring effective strategic management at different levels is noted. Taking into account the transformation of the essence of strategic enterprise management and the significant dependence of its effectiveness on professional competence of strategic decision developers and executors of their decisions, the essence of the competence-based approach is specified. It provides for the involvement of specialists with the necessary knowledge, skills, ability to objectively perceive information, use experience and intuition in determining promising areas of action, and take responsibility for decisions to achieve strategic goals for the implementation of the stages of strategic analysis and strategic selection. This will allow managers to involve employees in the process of making strategic decisions, focusing not only on their job positions, but primarily on the availability of a set of competencies necessary for strategic management and the appropriate level of their manifestation in professional behavior. A likely result can be a reduction in the time for the implementation of the relevant stages of strategic management and an increase in the likelihood of achieving strategic goals due to a correctly chosen strategy of future actions.
\end{abstract}

Keywords

JEL Classification

I. А. Грузіна (Україна) strategic management, competency approach, competence, staff

\section{СУТНІСТЬ ТА ОСОБЛИВОСТІ КОМПЕТЕНТНІСНОГО ПІДХОДУ ДО СТРАТЕГІЧНОГО УПРАВЛІННЯ ПІДПРИЕМСТВОМ}

\section{Анотація}

Підвищення ролі працівника, як визначального фактору економічного зростання підприємства, змушує керівників змінювати філософію управління, спрямовуючи іiі на реалізацію унікальних здібностей працівників. Ефективність реалізації стратегічного напряму дій залежить від знань, вмінь, особистісних характеристик фахівців, тобто компетенцій, які $€$ джерелом конкурентних переваг та стратегічним фактором розвитку підприємства. Це вимагає дослідження особливостей компетентнісного підходу для виявлення можливостей застосування у стратегічному управлінні підприємством. Метою дослідження є уточнення сутності компетентнісного підходу та обгрунтування необхідності застосування у стратегічному управлінні. Об’єкт дослідження - процес стратегічного управління підприємством. Використано методи: абстрактно-логічний, аналізу і синтезу - для уточнення сутності компетентнісного підходу; формування висновків; графічний - для візуалізації результатів. Проаналізовано погляди на сутність компетентнісного підходу та зазначено про недостатнє дослідження його значення для забезпечення ефективного стратегічного управління на різних рівнях. Зважаючи на трансформацію сутності стратегічного управління підприємством та суттєву залежність його ефективності від професійної компетентності 
розробників стратегічних рішень та їх виконавців, уточнено сутність компетентнісного підходу, що передбачає залучення для реалізації етапів стратегічного аналізу й стратегічного вибору фахівців, які вже володіють необхідними знаннями, навичками, вмінням неупереджено сприймати інформацію, використовувати досвід та інтуїцію у визначенні перспективних напрямів дій, брати відповідальність за прийняті рішення для досягнення стратегічних Це дозволить керівниками залучати до процесу розробки стратегічних рішень працівників, орієнтуючись не лише на посади, які вони обіймають, а, перш за все, на наявність необхідної для стратегічного управління сукупності компетенцій та відповідний рівень їхнього прояву у професійній поведінці. Ймовірним результатом може стати скорочення часу на реалізацію відповідних етапів стратегічного управління та підвищення вірогідності досягнення стратегічних цілей завдяки правильно обраній стратегії майбутніх дій.

\section{Ключові слова}

Класифікація JEL стратегічне управління, компетентнісний підхід, компетенція, компетентність, персонал

M10, M14, M21, M51

\section{ВСТУП}

Підвищення ролі стратегічного управління для сучасних підприємств обумовлюється, перш за все, кардинальною зміною умов їхнього функціонування внаслідок глобалізації бізнесу. Високий рівень нестабільності міжнародного середовища вимагає не лише розробки ефективної системи стратегічного управління, а й дієвого комплексу заходів для забезпечення її функціонування з метою зміцнення позиції підприємства на міжнародному ринку [13]. Переваги у конкурентній боротьбі, на думку теоретиків та практиків $[1-3 ; 6 ; 11 ; 18 ; 21]$, матимуть стратегічно орієнтовані підприємства, де застосовується система стратегічного управління, а персонал відрізняється стратегічним мисленням. Це надасть змогу розробляти та використовувати інтегровану систему стратегічних планів й, відповідно, підпорядкувати поточну діяльність досягненню встановлених стратегічних цілей. Але слід враховувати практичний досвід, відповідно до якого, впровадження стратегічного управління можливе, як правило, лише на тих підприємствах, де готові йти на революційні зміни, обумовлені динамікою зовнішнього середовища.

Які $б$ визначення стратегічного управління не використовувались дослідниками, які б засоби його впровадження у практичну діяльність підприємств не реалізовували сучасні керівники, незаперечною залишається точка зору, що воно, перш за все, спирається на людський потенціал, а його ефективність суттєво залежить від знань, навичок, майстерності тих працівників, які приймають безпосередню участь у розробці та реалізації стратегічних планів та рішень, програм та проектів, виробленні та обгрунтуванні стратегій майбутньої діяльності. I, якщо раніше стратегія формулювалась, переважно, вищим керівництвом підприємства, то сьогодні до їі розробки, а, тим більше, до реалізації залучаються майже усі рівні управління. Саме персонал, його компетентність, що відображує професійно-кваліфікаційні й особистісні характеристики, стає стрижнем розробки та ефективної реалізації стратегії майбутньої діяльності підприємства. Отже, повноцінна підтримка прийняття стратегічних рішень можлива лише за умови реалізації комплексного підходу, що враховує взаємозв’язок факторів нестабільного зовнішнього середовища, внутрішні фактори підприємства, його ресурси та компетентність.

\section{1. ЛІТЕРАТУРНИЙ ОГЛЯА}

Аналізуючи практику діяльності сучасних підприємств, можна спостерігати суттєві відмінності у підходах до розробки та реалізації стратегій, пошуку та набуття довгострокових конкурентних переваг, виявлення шляхів вирішення існуючих проблем. Представники так званого ресурсно-компетентнісного підходу - Архіпов та Верховська [3], Пфанштель [19] - здійснюють постійні спроби пояснити ці відмінності з позицій наявних у підприємств ресурсів і компетенцій. На їх думку, компетенції є запорукою дієвості стратегії підприємства та джерелом його стійкої конкурентної переваги.

Дослідженням значущості компетенцій персоналу та підприємства в цілому внаслідок стрімкого розвитку високих технологій, що суттєво впливають на сучасний ринок праці та формують нові вимоги до конкурентоспроможності фахівців, займались Комаров, Іванова, Сафронов, Новожонов [10].

Питання обов'язкового врахування конкретних властивостей людини для виконання певних завдань почали обговорюватись вченими ще декілька десятиріч тому. У результаті досліджень менеджерів 3 найма організацій всіх форм власності, які здійснювались консалтинговою групою Leadership IQ, було 
виявлено, що для керівників вищої та середньої ланки, які приймають безпосередню участь у процесі стратегічного управління підприємством, найціннішими $\epsilon$ не технічні вміння і навички, а поведінкові компетенції. Вже у той час $81 \%$ керівників 312 компаній були неуспішними саме з особистісних причин й лише $11 \%$ демонстрували незадовільний рівень необхідних технічних навичок [15].

Деякі науковці - Басинська, Радюк - пояснюють даний факт зростанням рівня посади та складності професійних обов’язків, через що питома вага професійних компетенцій падає, а особистісних - зростає [4].

Вирішенням проблем формування компетентності персоналу як об'єкта стратегічного управління підприємством та застосування компетентнісного підходу у даному процесі займаються: Близнюк, Богиня, Грішнова, Крушельницька, Лісогор, Мельничук, Петрова та інші [11].

Враховуючи вищевикладене, можна відзначити:

- теоретичну та практичну цінність ресурсно-компетентнісного підходу, що підтверджує залежність результатів розробки й реалізації стратегії, та, відповідно, ефективності діяльності підприємства від якості знань, умінь та досвіду, які колективно або індивідуально наявні у працівників, тобто від їх компетенцій; а також дозволяє чітко усвідомити необхідні для підприємства у певний момент часу ресурси і компетенції й відображує ті з них, які слід розвивати для забезпечення ефективного досягнення стратегічних цілей і завдань підприємства;

- виключну важливість накопичення знань, інформації, розвитку науки і технологій, тобто нематеріальних форм багатства, що стало вирішальним фактором економічного зростання й підвищення якості життя будь-якої держави, а також причиною підвищення вимог до рівня освіченості працівників, оскільки швидкість оновлення знань, яка вже досягла одного циклу у 3-5 років та продовжує зростати, обумовлює у найближчій перспективі необхідність нових знань для вирішення працівником практично кожного наступного завдання;

- необхідність радикальної трансформації сучасної системи стратегічного управління, яка має являти собою взаємопов'язані управлінські дії з першочерговим налагодженням високопрофесійного наукового, аналітичного та прогностичного супроводу розробки та реалізації управлінських рішень $з$ максимальним залученням знань, вмінь, професійної майстерності причетних до цього процесу працівників. Це має починатися з процедури відбору персоналу, виявлення талановитих співробітників з необхідним набором навичок, досвіду і поведінкових характеристик, та включати управління ефективністю їхньої праці;

- існування, незважаючи на наукову популярність даного питання, низки невирішених проблем, пов'язаних із нерозумінням або невірним розумінням сутності компетентнісного підходу, принципів його використання у процесі стратегічного управління підприємством, та ступеню впливу компетентності як окремих працівників, так і підприємства в цілому, на ефективність реалізації обраної стратегії майбутньої діяльності.

Це все вимагає подальшого дослідження сутності компетентнісного підходу, дослідження його категоріального апарату та технології його впровадження у систему стратегічного управління сучасним підприємством.

\section{2. МЕТА ДОСЛІДЖЕННЯ}

Метоюстаттієуточнення сутності компетентнісного підходута обгрунтування необхідності застосування у стратегічному управлінні.

\section{3. МЕТОАИ ДОСЛІДЖЕННЯ}

Для досягнення мети в роботі було використано загальнонаукові і спеціальні методи дослідження: абстрактно-логічний, аналізу і синтезу - для уточнення сутності компетентнісного підходу; формування висновків та узагальнення інформації; графічний - для візуалізації викладених положень. 


\section{4. РЕЗУЛЬТАТИ}

Людина сьогодні є джерелом знань, інформації та інновацій, а також головною цінністю суспільства й визначальним фактором економічного зростання. Ефективність ï праці можна суттєво підвищити шляхом реалізації унікальних індивідуальних здібностей, як то знань, досвіду, вмінь та особистісних характеристик, які проявляються у професійній діяльності. Сьогодні слід чітко усвідомити, що дієвість розробленої стратегії та ефективність виконання професійних завдань, зокрема, стратегічної спрямованості, не визначаються високими результатами традиційних академічних тестів здібностей і знань, як і наявністю будь-яких дипломів у потенційних виконавців роботи та багаторічного досвіду роботи на відповідних посадах. Суттєвими у процесі розробки та реалізації стратегічного напряму дій підприємством $€$ сукупність знань, вмінь, навичок фахівців, їх особистісні характеристики, особливості поведінки, тобто так звані компетенції, які формують компетентність як кожного працівника, так і сукупну компетентність підприємства, що $є$ джерелом його конкурентних переваг та стратегічним фактором розвитку. Це досить часто вимагає від сучасних підприємств зміни самої філософії управління, підходів та режимів роботи, орієнтації, передусім, не на активи, а на можливості - нові ринки, нові інноваційні продукти, розвиток людського потенціалу та організаційного навчання із підвищенням його швидкості і гнучкості.

Успішні підприємства відрізняються постійним прагненням до виходу на якісно новий рівень діяльності, послідовно створюючи нові знання, розповсюджуючи їх у межах підприємства й швидше за конкурентів оновлюючи асортимент товарів і послуг. Вони змушені створювати гнучкі системи взаємовідносин 3 партнерами і співробітниками, що адекватно реагують на зміни, розробляти дієві стратегії з постійним переглядом пріоритетів у розвитку підприємства [12]. За цих обставин очевидною стає необхідність формування та практичного використання компетенцій персоналу, який приймає безпосередню участь у розробці та реалізації стратегій діяльності підприємства, тобто питання застосування компетентнісного підходу в управлінні набувають стратегічного значення.

Все частіше теоретики та практики з управління замислюються над питанням, яким чином у швидкозмінних умовах функціонування, при дефіциті висококваліфікованих трудових ресурсів та одночасному зростанні ступеню залежності підприємств від кваліфікації співробітників, підтримувати бажаний рівень ефективності, розвиватися та досягати успіхів на висококонкурентних ринках. Науковці вважають, що саме компетентнісний підхід може стати основою, що дозволить розробити систему, яка 6 ефективно поєднувала вимоги бізнесу та задовольняла актуальні потреби персоналу. Цей факт науковці зрозуміли досить давно, коли Мак-Клелланд, досліджуючи «компетенції» та визначаючи їх як характеристики, що відрізняють і прогнозують рівень ефективності виконання роботи у конкретних виконавців, безпосередньо пов’язував ефективність виконання роботи з наявністю у їі виконавця певних компетенцій. Для формулювання цих висновків він вивчав характеристики успішних виконавців роботи і порівнював їх з характеристиками, які демонструють менш успішні виконавці тієї ж роботи [2]. Вчений, розглядаючи підприємство у вигляді певної ієрархічної системи прийняття управлінських рішень, зазначав, що кожний з них потребує специфічних компетенцій, які забезпечують набуття нових чи підсилення вже існуючих конкурентних переваг підприємства.

Сучасна практика управління підтримує розвиток компетентісного підходу та усвідомлює підвищення його ролі у забезпеченні ефективної діяльності підприємств, що обумовлює активізацію наукових дискусій [25]. Вчені погоджуються, що компетентний та мотивований до професійного розвитку працівник $є$ найголовнішою конкурентною перевагою підприємства, фахівці у галузі управління персоналом, розуміючи переваги компетентнісного підходу, намагаються впроваджувати його у практичну діяльність підприємств [7].

Однак, сучасні керівники, визнаючи залежність стабільного економічного розвитку підприємства від конкурентоспроможної робочої сили, ії професійно-кваліфікаційних властивостей, не завжди приділяють увагу особистісним характеристикам працівників, не усвідомлюють, що саме компетентність персоналу $€$ мірилом його знань, вмінь й навичок та важливою складовою стратегічного управління підприємством. 
Приймаючи до уваги існування зазначеної проблеми, доцільним є дослідження точок зору науковців на природу і зміст компетентнісного підходу з метою уточнення його сутності з огляду на необхідність використання для підвищення ефективності стратегічного управління підприємством (Таблиця 1).

\section{Таблиця 1. Наукові підходи до трактування сутності компетентнісного підходу}

Джерело: Складено за [2; 5; 9; 16; 17; 19; 20; 22-25; 27].

\section{Компетентнісний підхід}

Автор, джерело

1) передбачає формування у майбутніх фахівців професійної компетентності; використання відповідних освітніх технологій у навчанні, рефлексію студентів, самостійність застосування у практичній діяльності професійних умінь і навичок;

2) переміщує акценти з процесу накопичення нормативно визначених знань, умінь і навичок майбутніх фахівців у площину формування і розвитку здатності практично діяти і творчо застосовувати набуті знання і досвід у різних ситуаціях;

3) не заперечуючи значення знань, акцентує увагу на здатності їх використання. передбачає зорієнтованість на розвиток системного комплексу умінь, смислових орієнтацій, адаптаційних можливостей, досвіду і способів трансформаційної діяльності з отриманням конкретного продукту.

1) спрямовує освітній процес на формування та розвиток ключових (базових, основних) i предметних компетентностей особистості;

2) скеровує освіту на формування цілого набору компетентностей (знань, умінь, навичок, ставлень тощо), якими мають оволодіти майбутні фахівці

3) фокусує увагу не на самих знаннях, а на тому, для чого вони потрібні.

це актуалізація професійних знань і вмінь у діяльності за допомогою вирішення проблемних завдань, творчості, самоаналізу, а також досвіду і способів перетворювальної діяльності із здобуттям конкретного результату.

1) описує не стільки знання і навички людини, скільки модель професійної поведінки, за допомогою якої встановлюється прямий зв'язок застосовуваних знань, умінь і навичок з конкретними, вимірюваними результатами трудової діяльності працівника;

2) пояснює причини трудового успіху або невдачі, вказує не тільки на здатність людини здійснювати необхідну професійну діяльність, але і нести за неї відповідальність, усвідомлювати, яким чином досягається потрібний результат;

3) сприяє реалізації бізнес-стратегії розвитку підприємства та активізує саморозвиток і самоорганізацію персоналу, оскільки активна участь в процесах поліпшення діяльності підприємства неможлива без залучення працівників до самостійного пошуку, розвитку знань і індивідуальних здібностей.

1) спрямований на навчання працівника управляти власними знаннями, навичками і вміннями, тобто вміти самонавчатися і саморозвиватися;

2) використовує для опису компетенцій різні характеристики, тобто прояв в поведінці знань, навичок і якостей, за якими можна визначити наявність компетенції працівника; описує конкретні прояви професіоналізму співробітника при виконанні робочих завдань.

1) виводить на перший план потенціал співробітника - здатності, мотивацію і поведінкові установки, тобто звертається до явних і прихованих можливостей працівників, створюючи потужний імпульс до їх активної участі в діяльності організації, зростання задоволеності працею, і формування на цій основі постійної потреби в удосконаленні знань, умінь і компетенцій;

2) переорієнтує мету управління персоналом від вирішення оперативних кадрових проблем (наприклад, своєчасність навчання співробітників або заміщення керівних посад) до завдань більш високого стратегічного порядку.

1) враховує психологічний аспект оцінки персоналу (моделювання необхідної трудової поведінки), пов'язаний із моделюванням необхідної трудової поведінки, поряд з ефектами економічним (поліпшення фінансових і комерційних показників), соціальним (підвищення задоволеності результатами праці як персоналу, так і роботодавця);

2) передбачає оцінку персоналу через порівняння результативності, якості та складності здійсненої праці з еталонними характеристиками на даній посаді.

базуючись на змісті понять «компетенція» і «компетентність», визначає коло тих аспектів, на які слід звертати увагу при управлінні персоналом підприємства. 
Аналізуючи наведені визначення, можна дійти висновку, що найрозповсюдженішим компетентнісний підхід $\epsilon$ в освітній сфері, зокрема, у сфері фахової освіти, що пов’язано з реформуванням традиційних освітніх моделей [12]. Також досить часто зустрічаються результати наукових розробок та емпіричних досліджень вітчизнянихтазахідних теоретиків тапрактиківщодо трактування сутностікомпетентнісного підходу з орієнтацією на вирішення питань управління персоналом сучасних підприємств [26].

Незрозумілим є той факт, що, незважаючи на домінування з початку 90-х років в теорії і практиці стратегічного управління ресурсної концепції, відповідно до якої стійкий успіх підприємства та його конкурентні переваги залежать від наявності унікальних ресурсів і організаційних здібностей (компетенцій) [8], у наукових колах недостатньо приділено уваги дослідженню сутності, ролі та значення компетентнісного підходу саме для забезпечення ефективного стратегічного управління на різних рівнях. I це стосується не лише необхідності ідентифікації та подальшого розвитку ключових компетенцій відповідно до стратегічних цілей підприємства з урахуванням змін у зовнішньому середовищі [8]. Не менш важливим $\epsilon$ вміння менеджменту розробляти дієві стратегії майбутньої діяльності з урахуванням наявних унікальних ресурсів, консолідувати розосереджені технології і виробничі навички в компетенції, залучати нових компетентних працівників, й зберігати досвідчених і компетентних співробітників підприємства. Все це можливо завдяки реалізації компетентнісного підходу в межах стратегічного управління. Компетентність управлінського персоналу також стає стратегічним ресурсом та джерелом конкурентної переваги підприємства, адже пошук нових можливостей, формулювання дієвих стратегій та їх успішна реалізація немислимі без наявності внутрішніх здібностей приймати раціональні стратегічні рішення та вмінь їх реалізувати.

На думку переважної більшості фахівців зі стратегічного управління, роль професійної компетентності як управлінського персоналу, так і безпосередньо виконавців робіт, постійно зростає, стає вирішальною у підвищенні ефективності господарської діяльності, поступово набуваючи стратегічного значення [26]. Вкрай важливо сьогодні навчитися визначати необхідні компетенції і здібності з метою забезпечення їх оптимальної конфігурації. Слід розуміти, що і історія підприємства, й накопичений досвід, його характер, культура, сильні сторони і можливості - все це $є$ факторами впливу на формування стратегії, що визначають ï успіх [6]. Безсумнівно, важливим чинником забезпечення ефектної реалізації стратегічних цілей підприємства сьогодні $\epsilon$ персонал, його знання, досвід, кваліфікація, здатності виробляти судження і приймати ризики, що, у свою чергу, визначають потенціал підприємства та його стратегічні можливості [21].

Компетентнісний підхід став відображенням змін у характері і змісті праці, професійному навчанні та освіті. Серед його основних переваг науковці виділяють: базування на виокремленні переліку компетентностей, що відрізняються від знань працівників якісною професійною діяльністю, а не тільки теоретичною інформацією про неї; відмінність компетентностей від класичного розуміння умінь перенесенням їх на різні об'єкти впливу; розгляд навичок як усвідомленості, яка дозволяє людині діяти навіть у нестандартних ситуаціях [7]. Зважаючи на вищевикладене та враховуючи необхідність пошуку відповідних сучасним реаліям підходів до забезпечення успішної довгострокової діяльності сучасних підприємств, обумовлену непередбачливістю умов їх функціонування з високим ступенем невизначеності та динамічності, актуальним стає дослідження сутності компетентнісного підходу та його складових, визначення якісного складу відсутніх або недостатньо розвинутих компетенцій підприємства, збалансування їх складу, взаємозв'язку та впливів на процес забезпечення стратегічного успіху підприємства та його довгострокового функціонування.

Формуючи уявлення про сутність та зміст компетентнісного підходу у межах стратегічного управління, слід враховувати, що впродовж останніх десятиліть відбувається певне теоретичне коригування сутності та методологічного навантаження поняття стратегічного управління, й формування діаметрально протилежних його трактувань. Окрім цього, сучасний етап розвитку теоретичного підгрунтя та практики реалізації стратегічного управління відрізняється багатовекторністю, виникненням протиріч між плановістю і спонтанністю, конкуренцією і партнерством, між регламентованістю і гнучкістю управлінських рішень для вирішення актуальних завдань, що також обумовлює певні особливості компетентністного підходу. 
Безсумнівно, ефективність управління, не лише сьогодні, але й у перспективі, суттєво залежить від ступеня опанування керівниками методології і методів стратегічного управління. Однак, перш, ніж впроваджувати компетентнісний підхід у практику стратегічного управління, слід проаналізувати дослідницькі підходи до розуміння сутності стратегічного управління з метою розкриття його теоретикопрактичної цінності та з'ясування методологічної суперечливості щодо визначення його змісту, корисно. Усвідомлення сутності компетентнісного підходу, його змісту та базових категорій можливе лише за умови окреслення ключових змін у природі сучасного стратегічного управління, аналізу основних чинників трансформації сутності стратегічного управління та специфіки розробки і реалізації стратегічних рішень (Рисунок 1).

Щодо чинників, які зумовлюють трансформацію поглядів на сутність стратегічного управління, то, по-перше, посилення турбулентності, наростаючий темп змін та високий рівень невизначеності $€$ факторами стрімкого скорочення часового лагу бачення майбутнього, що зумовлює обов’язкове впровадження в операційну діяльність підприємства стратегічного мислення та набуття стратегічним процесом статусу регулярного управлінського бізнес-процесу. По-друге, постійна зміна ділового середовища й відсутність можливості спрогнозувати дії його учасників суттєво ускладнює досягнення результатів, встановлених прийнятими стратегічними рішеннями. Неможливість чіткого передбачення майбутніх ринкових тенденцій, а також чинників розвитку підприємств суттєво ускладнюють розробку будь-якого прогнозу розвитку за допомогою традиційного методу екстраполяції минулих тенденцій у зовнішньому та внутрішньому середовищі. Цей факт, підкреслюючи безперспективність акцентування уваги на емпіричних даних для визначення існуючих тенденцій в умовах функціонування підприємств та їх проекції на перспективу для визначення напрямів і темпів їх розвитку, обумовлює необхідність перегляду методично-аналітичного інструментарію стратегічного аналізу, що $є$ важливим етапом процесу розробки стратегічних рішень.

По-третє, ускладнення процесу обгрунтування стратегічних рішень та зниження рівня якості їх аналітичної підготовки через суттєве зниження дієвості кількісних методів досліджень та рівня їх прогностичної достовірності провокує зростання рівня ірраціональності у прийнятті управлінських рішень. Знову ж таки, основною причиною $є$ відсутність адекватного інструментарію оцінювання якості стратегічного управління. По-четверте, поширення методу партисипативного управління, особливістю якого є залучення більшості менеджерів підприємства до процесу прийняття управлінських рішень, суттєво розширює коло учасників процесу стратегічного управління, не обмежуючись лише топменеджментом, що, безумовно, потребує модифікації існуючих форм організації процесу прийняття стратегічних рішень та розробки стратегії, методів мотивації співробітників, системи делегування повноважень та, відповідно, відповідальності за прийняття і реалізацію стратегічних рішень.

Ситуацію ускладнює постійна зміна у реальній дійсності внутрішніх і зовнішніх зв’язків економічних систем, а, відповідно, і зміна умов функціонування традиційних структур управління, їхніх елементів і субординації. Швидкий розвиток технологій, ускладнення і розмаїття товарів і послуг, скорочення їхнього життєвого циклу, поява великого числа конкурентоспроможних підприємств, що провокує підвищення вимог покупців, збільшення обсягів і швидкості отримання інформації та нових знань, змушують сучасні підприємства шукати нові підходи до управління. Крім того, зростаюча тенденція щодо невизначеності, непередбачуваності і нестабільності зовнішнього середовища, поглиблення та прискорення змін у ньому вимагають від управління вміння адаптуватися як до поточних, так і до перспективних умов господарювання.

Як свідчить Рисунок 1, стратегічне управління спирається на стратегічний потенціал підприємства, зокрема, на людський потенціал, як його невід'ємну складову. Оскільки можна сказати, що наявність у працівника певних компетенцій створює його внутрішній потенціал та визначає так звану ступінь його готовності до ефективної роботи у конкретній робочій ситуації, а його компетентність у певній сфері професійної діяльності є передумовою успішної роботи у межах конкретної посади або підприємства в цілому, то застосування компетентнісного підходу у стратегічному управлінні стає сьогодні безсумнівною необхідністю. 


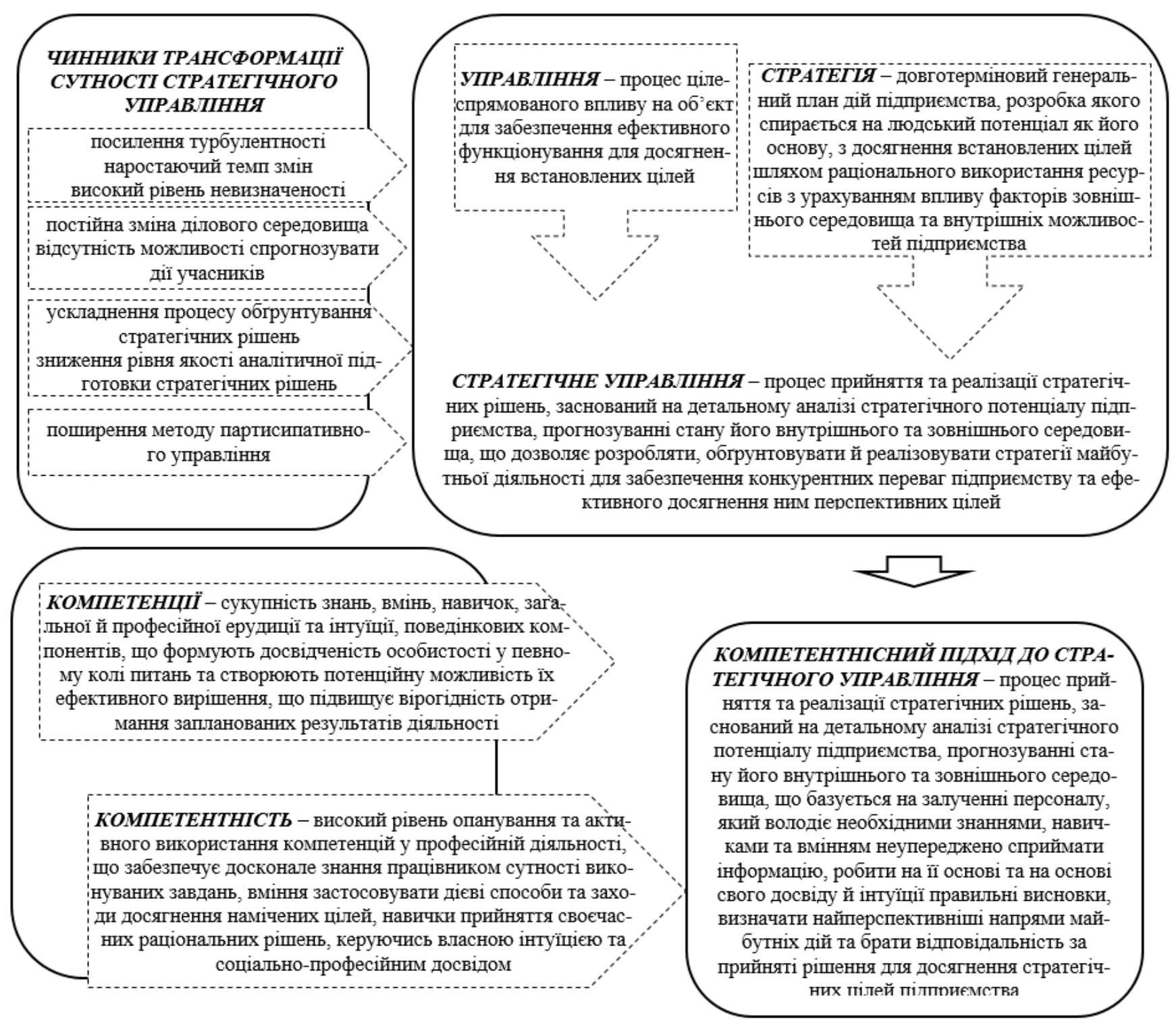

Джерело: Власна розробка автора.

\section{Рисунок 1. Сутність компетентнісного підходу до стратегічного управління підприємством}

Враховуючи специфіку стратегічного управління підприємством, його характеристики та особливості, доцільним у межах даного дослідження $\epsilon$ визначення сутності та змісту компетентнісного підходу не лише з позиції встановлення стратегічних цілей з урахуванням динаміки змін зовнішнього середовища, включаючи створення, нарощування та ефективне використання ключових компетенцій підприємства, так званих ключових факторів успіху для їх досягнення [18], що є, безумовно, вкрай важливою та необхідною складовою стратегічного управління в сучасних умовах. Не менш важливим для розробки ефективних стратегій майбутньої діяльності підприємства $є$ компетентність персоналу, що приймає безпосередню участь у даному процесі. Тобто мова йде про залучення до процесу стратегічного управління підприємством персоналу, який має так звану необхідну модель професійної поведінки, що не лише сприяє розробці та реалізації бізнес-стратегії підприємства, а й передбачає здійснення самостійного пошуку, розвиток знань і індивідуальних здібностей. Такий підхід сприяє формуванню так званої «компетентної організації», що включає і особисту репутацію, і талант топ-менеджерів, i особливості організаційних відносин, і формування міцної корпоративної культури, тобто володіє усіма необхідними компетентностями для успішного довгострокового функціонування підприємства. 


\section{ВИСНОВКИ}

За результатами проведеного дослідження можна визначити наступне:

1) опубліковані у науковій літературі результати теоретичних та емпіричних досліджень свідчать про нечіткість, а інколи взагалі невизначеність понятійного апарату компетентнісного підходу. Поліваріантність тлумачення одних і тих самих понять та категорій створює термінологічну плутанину у визначеннях їх сутності та критеріїв їх розмежування, що гальмує розвиток методичного інструментарію та ускладнює процес впровадження прогресивних методів стратегічного управління у практику сучасного підприємства. Актуальним за цих обставин $є$ визначення та групування основних елементів компетентнісного підходу, його тлумачення як основної складової стратегічного управління й чинника конкурентоспроможності підприємства;

2) аналіз підходів до теоретичного коригування сутності та методологічного навантаження поняття стратегічного управління дозволяє стверджувати, що воно сьогодні спирається на стратегічний потенціал підприємства, зокрема, на людський потенціал, як його невідєєну складову, а його ефективність суттєво залежить від знань, навичок, майстерності тих працівників, які приймають безпосередню участь у розробці та реалізації стратегічних планів та рішень, програм та проектів, виробленні та обгрунтуванні стратегій майбутньої діяльності;

3) наявність у працівника певних компетенцій створює його внутрішній потенціал та визначає ступінь його готовності до ефективної роботи у конкретній робочій ситуації. Компетентність працівника, що $€$ рівнем опанування та активного використання компетенцій у певній сфері професійній діяльності, $€$ передумовою успішної роботи у межах конкретної посади або підприємства в цілому. Саме персонал, його компетентність, що відображує професійно-кваліфікаційні й особистісні характеристики, стає стрижнем розробки та ефективної реалізації стратегії майбутньої діяльності підприємства. Тобто очевидною сьогодні стає необхідність застосування компетентнісного підходу до стратегічного управління підприємством;

4) враховуючи специфіку стратегічного управління підприємством, його характеристики та особливості, уточнено сутність компетентнісного підходу, який розглядається не лише з позиції встановлення стратегічних цілей з урахуванням динаміки змін зовнішнього середовища, але й необхідності залучення до процесу стратегічного управління підприємством персоналу, який має так звану необхідну модель професійної поведінки, що не лише сприяє розробці та реалізації бізнес-стратегії підприємства, а й передбачає здійснення самостійного пошуку, розвиток знань і індивідуальних здібностей;

5) усвідомлення сучасними керівниками підприємств необхідності залучення до реалізації етапів стратегічного аналізу й вибору фахівців, які вже володіють необхідними знаннями та навичками, вмінням використовувати досвід та інтуїцію у визначенні перспективних напрямів дій для досягнення стратегічних цілей, дозволить їм здійснювати вибір працівників, орієнтуючись не лише на посади, які вони обіймають, а, перш за все, на наявність необхідної для стратегічного управління сукупності компетенцій та відповідний рівень їхнього прояву у професійній поведінці;

6) неможливість визначити компетентнісний підхід як стійке явище управлінської дійсності, його знаходження сьогодні в стадії розвитку, або, навіть, формування, актуалізує необхідність визначення та групування основних елементів компетентнісного підходу, його тлумачення як основної складової стратегічного управління й чинника конкурентоспроможності підприємства. Відсутність загальноприйнятого погляду на типологію і структуру компетенцій, нечіткість, а інколи невизначеність понятійного апарату компетентнісного підходу, створює певну термінологічну плутанину. Це обумовлює необхідність подальшого дослідження, спрямованого на уточнення сутності понять «компетенція» та «компетентність», їх принципових відмінностей, виявлення певних видів компетенцій з урахуванням особливостей діяльності працівників, аналіз існуючих методик відбору та залучення персоналу до виконання певного виду завдань, зокрема, стратегічної спрямованості, розробку напрямів їх удосконалення з метою найефективнішого застосування компетентісного підходу у процесі стратегічного управління підприємством. 


\title{
AUTHORS CONTRIBUTIONS
}

\author{
Conceptualization: Inna Gruzina. \\ Data curation: Inna Gruzina. \\ Investigation: Inna Gruzina. \\ Methodology: Inna Gruzina. \\ Visualization: Inna Gruzina. \\ Writing - review \& editing: Inna Gruzina.
}

\section{СПИСОК ЛІТЕРАТУРИ}

1. Analoui, F., \& Karami, A. (2005). Strategic management of small and medium enterprises [Strategicheskoye upravleniye malym i srednim biznesom] (400 p.). Moscow: UNITY-DANA. (In Russian)

2. Arapova, O., Fridrif, V., \& Modyrka, V. (2013). Competence approach as a factor in increasing the competitiveness of the enterprise [Kompetentnisnyi pidkhid yak chynnyk pidvyshchennia konkurentospromozhnosti pidpryiemstva]. Economics: time realities, 1(6), 207-211. (In Ukrainian). Retrieved from http://nbuv.gov.ua/UJRN/econrch_2013_1_39

3. Arkhipov, V., \& Verkhovskaya O. (2007). Strategic management [Strategicheskiy menedzhment]. SPb: SPbGUEF. (In Russian)

4. Basinskaya, I., \& Radyuk, O. (2013). Competence-based approach in the human resources management. Humanitarian and Economic Bulletin - Humanitarno-ekonomichnyi visnyk, 3, 81-87. (In Russian)

5. Chulanova, O. (2013). The concept of a competence-based approach to personnel management [Kontseptsiya kompetentnostnogo podkhoda $\mathrm{v}$ upravlenii personalom]. Knowledge sciences - Naukovedeniye, 5. (In Russian)

6. Efremov, V., \& Khanykov, I. (2002). Klyuchevaya kompetentsiya organizatsii kak obyekt strategicheskogo analiza [The key competence of the organization as an object of strategic analysis]. Management in Russia and Abroad, 2. (In Russian). Retrieved from https://www.cfin. $\mathrm{ru} /$ press/management/2002-2/02.shtml

7. Guiyar, F., \& Kelli, D. (2000). Business Transformation [Preobrazovaniye organizatsii]. Moskva: Delo. (In Russian)

8. Khemel, G., \& Prakhalad, K. (2002). Competition for the future [Konkurentsiya za budushcheye]. Moskva: Olimp-Biznes. (In Russian)

9. Khymynets, V. (2009). Innovative educational activities [Innovatsiina osvitnia diialnist]. Ternopil: Mandrivets. (In Ukrainian)

10. Komarov, N., Ivanova, N., Safronov, V., \& Novozhonov, S. (2012). The influence of high-tech on the formation of requirements for the professional competence of specialists [Vliyaniye vysokotekhnologichnosti na formirovaniye trebovaniy k professionalnoy kompetentnosti spetsialistov]. Knowledge sciences - Naukovedeniye, 4. (In Russian)

11. Korchaka, S. (2010). Personnel competence as a component of strategic enterprise management [Kompetentnist personalu yak skladova stratehichnoho upravlinnia pidpryiemstvom]. Scientific Bulletin of PUET: Economic Sciences, 4(43), 220-223. (In Ukrainian). Retrieved from http://nbuv.gov.ua/UJRN/Nvpusk_2010_4\%283\%29_51

12. Ksenofontova, Kh. (2013). Strategic-competence approach of competence development of managerial staff. Modern Management Technology, 1(25). (In Russian). Retrieved from https://sovman.ru/article/2504/

13. Lukianenko, D., \& Kaliachenko, T. (2008). Global governance strategies [Stratehii hlobalnoho upravlinnia]. International economic policy Mizhnarodna ekonomichna polityka, 1-2, 5-8. (In Ukrainian). Retrieved from http://journals.uran.ua/jiep/article/view/27496

14. Mintzberg, H. (2004). The Rise and Fall of Strategic Planning: Reconceiving Roles for Planning, Plans, Planners. N. Y.: Free press.

15. Murphy, M. (2009). Hiring for Attitude: Research \& Tools to Skyrocket Your Success Rate. Retrieved from https://www.coursehero.com/ file/26073657/Hiring-For-Attitude-Summarypdf/

16. Mykolaichuk, I., \& Stryzhak, Ju. (2017). Competent approach in the personnel management system. Internauka. Series: Economic Sciences, 18(2), 53-56. (In Ukrainian). https://doi.org/10.25313/2520-2057-2017-18

17. Naghach, M. (2013). Training future teachers in school: the experience of pedagogical education in the United States [Pidhotovka maibutnikh uchyteliv u shkoli: dosvid pedahohichnoi osvity SShA]. Comparative and pedagogical studies - Porivnialno-pedahohichni studii, 2(16), 126-133. (In Ukrainian)

18. Nalyvajko, A. (2001). Theory of enterprise strategy. Current state and directions of development [Teoriia stratehii pidpryiemstva. Suchasnyi stan ta napriamky rozvytku] (227 p.). Kyiv: KNEU. (In Ukrainian)

19. Pfanshtel, V. (2014). Model of professional competencies of an effective consultant [Model professionalnykh kompetentsiy effektivnogo konsultanta]. Young scientist - Molodoy uchenyy, 6(65), 473-476. (In Russian). Retrieved from https://moluch.ru/archive/65/10625/

20. Pfanshtel, V. (2014). Resource-competence approach in strategic analysis of the external environment of trade organizations [Resursnokompetentnostnyy podkhod v strategicheskom analize vneshney sredy organizatsiy torgovli]. Young scientist - Molodoy uchenyy, 6(65), 476-480. (In Russian). Retrieved from https://moluch.ru/archive/65/10626/

21. Rachynsjkyj, A. (2009). Strategic management in the context of modern Western European approaches [Stratehichne upravlinnia $\mathrm{v}$ konteksti suchasnykh zakhidnoievropeiskykh pidkhodiv]. Bulletin of the National Academy of Public Administration under the President of Ukraine, 3, 12-20. (In Ukrainian). Retrieved from http://nbuv.gov.ua/UJRN/Vnadu_2009_3_4

22. Rudnitska, K. (2016). The essence of concepts of "competence approach», «competency», «competence», "professional competency» in the light of modern education paradigm. Scientific Bulletin of Uzhhorod University. Series: Pedagogy. Social Work, 1(38), 241-244. (In Ukrainian). Retrieved from http://nbuv.gov.ua/UJRN/Nvuuped_2016_1_61

23. Sinichenko, A. (2016). Competence approach as a modern paradigm of personnel management. Finance, accounting, banking, 1(21), 288-294. (In Ukrainian). Retrieved from http://nbuv.gov.ua/UJRN/Fub_2016_1_32

24. Stolyaruk, Kh. (2013). Development of the Role Scenario of the Personnel Management Specialist Activity. Business Inform, 12, 378-383. (In Ukrainian). Retrieved from http://nbuv.gov.ua/UJRN/binf_2013_12_69 
25. Strizhak, J. (2017). Competent approach in the personnel management system. Internauka. Series: Economic Sciences, 18(40), 2, 53-56. (In Ukrainian). Retrieved from http://nbuv.gov.ua/UJRN/mnj_2017_18\%282\%29_13

26. Sytnyk, N. (2010). Competence approach in human resource management [Kompetentnisnyi pidkhid v upravlinni liudskymy resursamy]. Economic bulletin of National technical university of Ukraine "Kyiv polytechnic institute», 7, 121-124. (In Ukrainian). Retrieved from https:// economy.kpi.ua/files/files/24_kpi_2010_7.pdf

27. Usacheva, A. (2013). Responsibility as a personal competence of a university student [Otvetstvennost kak lichnostnaya kompetentsiya studenta vuza]. In Civil Society and the Rule of Law: Proceedings of the Scientific and Practical Conference [Grazhdanskoye obshchestvo $i$ pravovoye gosudarstvo: materialy Nauchno-prakticheskoy konferentsii]. Svetlyy Yar: Feniks. (In Russian) 